\title{
Occurrence and biology of Dinocampus coccinellae (Schrank, 1802) (Hymenoptera; Braconidae: Euphorinae) parasitising different species of Coccinellidae (Coleoptera) in Neotropical region
}

\author{
Silva, RB. ${ }^{a, b *}$, Cruz, I. ${ }^{b}$ Figueiredo, MLC. ${ }^{b}$, Pereira AG. ${ }^{a}$ and Penteado-Dias AM. ${ }^{a}$ \\ aPrograma de Pós-graduação em Ecologia e Recursos Naturais, Departamento de Ecologia e Biologia Evolutiva - DEBE, \\ Universidade Federal de São Carlos - UFSCar, CP 676, CEP 13565-905, São Carlos, SP, Brazil \\ 'Laboratório de Criação de Insetos - LACRI, Embrapa Milho e Sorgo, \\ Rod. MG 424, Km 65, Zona Rural, CP 151, CEP 35700-970, Sete Lagoas, MG, Brazil \\ *e-mail: rafaelentomologia@yahoo.com.br \\ Received January 26, 2011 - Accepted March 28, 2011 - Distributed February 29, 2012
}

(With 1 figure)

\begin{abstract}
Surveys on Coccinellidae (Coleoptera) in Sete Lagoas city, Minas Gerais state, Brazil, indicated the parasitism of adults of the species Coleomegilla maculata De Geer, 1775, Eriopis connexa (Germar, 1824) and Olla v-nigrum (Mulsant, 1866), by Dinocampus coccinellae (Schrank, 1802) (Hymenoptera; Braconidae: Euphorinae). Since then, the parasitoid have been maintained in its original hosts at the Insect Rearing Laboratory - LACRI of the Brazilian Agricultural Research Institution - Embrapa Milho e Sorgo. Besides the citation of occurrence in Brazil, this work also indicates the parasitoid preference for C. maculata (70\% of parasitism), followed by $O$. v-nigrum (43.3\% of parasitism) and E. connexa (36.7\% of parasitism). Total life cycle of D. coccinellae was longer on C. maculata (32.4 \pm 0.48 days), compared to $O$. v-nigrum (29.5 \pm 0.49 days) and $E$. connexa ( $27.8 \pm 0.4$ days). Due to the relatively high percentage of field parasitism, $D$. coccinellae can reduce the efficiency of biological pest control by Coccinellidae predators especially in the case of C. maculata.
\end{abstract}

Keywords: biological control, ladybeetles, natural enemy, parasitoid, predator.

\section{Ocorrência e biologia de Dinocampus coccinellae (Schrank, 1802) (Hymenoptera; Braconidae: Euphorinae) parasitando diferentes espécies de Coccinellidae (Coleoptera) na região Neotropical}

\begin{abstract}
Resumo
Estudando os Coccinellidae na região de Sete Lagoas, Estado de Minas Gerais, Brasil, foram encontrados adultos de Coleomegilla maculata De Geer, 1775, Eriopis connexa (Germar, 1824) e Olla v-nigrum (Mulsant, 1866) (Coleoptera: Coccinellidae), parasitados por Dinocampus coccinellae (Schrank, 1802) (Hymenoptera; Braconidae: Euphorinae). O parasitoide, desde então, tem sido mantido em adultos desses Coccinellidae, no Laboratório de Criação de Insetos LACRI da Empresa Brasileira de Pesquisa Agropecuária - Embrapa Milho e Sorgo, em Sete Lagoas, MG, Brasil, onde o trabalho foi conduzido. Este trabalho relata a ocorrência de D. coccinellae em C. maculata, E. connexa e O. v-nigrum, e apresenta alguns aspectos biológicos desse parasitoide. Coleomegilla maculata apresentou maior suscetibilidade ao parasitoide, com $70 \%$ de adultos parasitados; O. v-nigrum e E. connexa apresentaram porcentagem de parasitismo de 43,3 e $36,7 \%$, respectivamente. O ciclo de desenvolvimento de $D$. coccinellae foi mais longo em $C$. maculata (32,4 \pm 0,48 dias) em relação a $O$. $v$-nigrum $(29,5 \pm 0,49$ dias $)$ e E. connexa (27,8 $\pm 0,40$ dias). A eficiência do controle biológico de pragas pelos predadores $C$. maculata, E. connexa e $O$. v-nigrum pode ser reduzida pela ocorrência do parasitoide D. coccinellae.
\end{abstract}

Palavras-chave: controle biológico, joaninhas, inimigo natural, parasitoide, predador. 


\section{Introduction}

Coccinellidae species (Coleoptera), known as "ladybeetle", are considered useful natural enemies feeding on phytophagous insect species and regulating their populations in many agricultural systems involving commercial crops (Obrycki et al., 2009; Lundgren, 2009; Isikber and Copland, 2002). Their preys are species of mites and insects such as: greenflies, aphids, eggs and neonate larvae of Coleoptera and Lepidoptera (Stathas, 2000; Lu et al., 2002; Omkar and Singh, 2006; Silva et al., 2009, 2010).

Many Coccinellidae species are efficient predators and easily adapt to both changes in quantity and quality of their prey (Segonça et al., 2005; Weber and Lundgren, 2009). Although recorded from several ecosystems, some of them show variability in the level of establishment of their populations, which leads to the reduction of its effectiveness. Possibly such species may be under the action of one or more species of natural enemies. Therefore, a better understanding of the factors involved in its performance in the field, could explain the low rate of predation serving as a basis for the correct choice of the species to make the most efficient biological control (Katsarou et al., 2005; Riddick et al., 2009).

In Brazil, works addressing the natural enemies of Coccinellidae are still scarce, reporting only its occurrence. Homolotylus flaminius (Dalman, 1820) (Hymenoptera: Encyrtidae), Phalacrotophora nedae (Malloch, 1912) (Diptera: Phoridae) and Dinocampus coccinellae (Schrank, 1802) (Hymenoptera; Braconidae: Euphorinae) were reported as larval, pupal and adult parasitoid from Cycloneda sanguinea (L., 1763) (Coleoptera: Coccinellidae), respectively (Gravena, 1978). Santos and Pinto (1981) also reported $D$. coccinellae as parasitoid of adult $C$. sanguinea.

The braconids Euphorinae includes endoparasitoids of adult Coleoptera, of the genus Dinocampus, parasitising mainly Coccinellidae species and Curculionidae (Hodek, 1973). Dinocampus coccinellae is a telitokous parthenogenetic solitary parasitoid (Balduf, 1926; Obrycki, 1989; Phillips and Emberson, 1999; Okuda and Ceryngier, 2000; Hoogendoorn and Heimpel, 2002; Riddick et al., 2009), whose females do not discriminate hosts which have already been parasitised by other females of the same species (Geoghegan et al., 1998; Majerus et al., 2000; Koyama and Majerus, 2008).

This work reports the occurrence in Brazil, of D. coccinellae in association with Coccinellidae species, Coleomegilla maculata De Geer, 1775, Eriopis connexa (Germar, 1824) and Olla v-nigrum (Mulsant, 1866) and presents some biological aspects related to each host.

\section{Material and Methods}

During monitoring work toward Coccinellidae species in the region of Sete Lagoas, Minas Gerais state, Brazil, the parasitoid $D$. coccinellae was found in association with adults of C. maculata, E. connexa and $O$. v-nigrum. This parasitoid, since then, has been maintained in laboratory conditions at the Insect Rearing Laboratory (LACRI) of the Brazilian Agricultural Research (Embrapa Milho e Sorgo) in Sete Lagoas. The experiment for the study of the biological aspects of $D$. coccinellae was conducted in chambers set at $25 \pm 1^{\circ} \mathrm{C}$, photoperiod of 12 hours and Relative Humidity of $70 \pm 10 \%$.

Three groups of eight females of $D$. coccinellae were kept in cages (glass container, $12 \mathrm{~cm}$ in diameter $\times 27 \mathrm{~cm}$ high), covered with PVC film. Drops of honey as food source for adult parasitoids were placed on the cage wall. In each cage, 30 adults of $C$. maculata, E. connexa or $O$. v-nigrum were introduced, which were obtained from LACRI.

The Coccinellidae remained in contact with parasitoids for 24 hours. After this period, they were removed from the cage and individually placed in a $50 \mathrm{~mL}$ plastic cup, covered with a transparent polystyrene lid. Adults were fed with artificial diet (Silva et al., 2009) and eggs of Anagasta kuehniella (Zeller, 1879) (Lepidoptera: Pyralidae).

Daily evaluations were based on the biological cycle of the parasitoid and behaviour of the hosts. Data were submitted to the non-parametric test of Kruskal-Wallis $(\mathrm{p}<0.05)$ (Kruskal and Wallis, 1952).

\section{Results}

The specimens of $D$. coccinellae were identified by one of the authors of this work (A.M.P.D.) and are deposited in the Coleção Entomológica do Departamento de Ecologia e Biologia Evolutiva - DCBU, Universidade Federal de São Carlos - UFSCar in São Carlos, São Paulo state, Brazil, and in LACRI.

Dinocampus coccinellae reproduction is a telitokous partenogenetic species. The female starts the parasitism process approximately one hour after its emergence. She moves the abdomen, placing it between its legs, extending the ovipositor slightly to the front of its head. In this position, the female found its prey. The parasitoid exhibits preference for those specimens in motion. Finding the host, the ovipositor was inserted into the posterior abdomen region between the elytra and membraceous wings.

The incubation period of $D$. coccinellae eggs has not been quantified; however, the time for the parasitoid larva to exit from Coccinellidae body to begin the process of pupation was observed.

Larvae of the parasitoid (Figures 1a,b) are yellow whitish in colour, with cylindrical and slightly flattened body, without legs but with prominent head; emerging from posterior of the abdomen of host, under the elytra.

The parasitoid, in some cases, makes use of the legs of Coccinellidae host (Figure 1c) during the process of pupation, leaving it imprisoned and deprived of food, leading to death, possibly by starvation; even with the pupa of the parasitoid formed, the Coccinellidae host remained alive. The pupa (Figure 1d) was formed on the bottom of the plastic cups, and the Coccinellidae host remained alive and visually similar to non-parasitised specimens. 

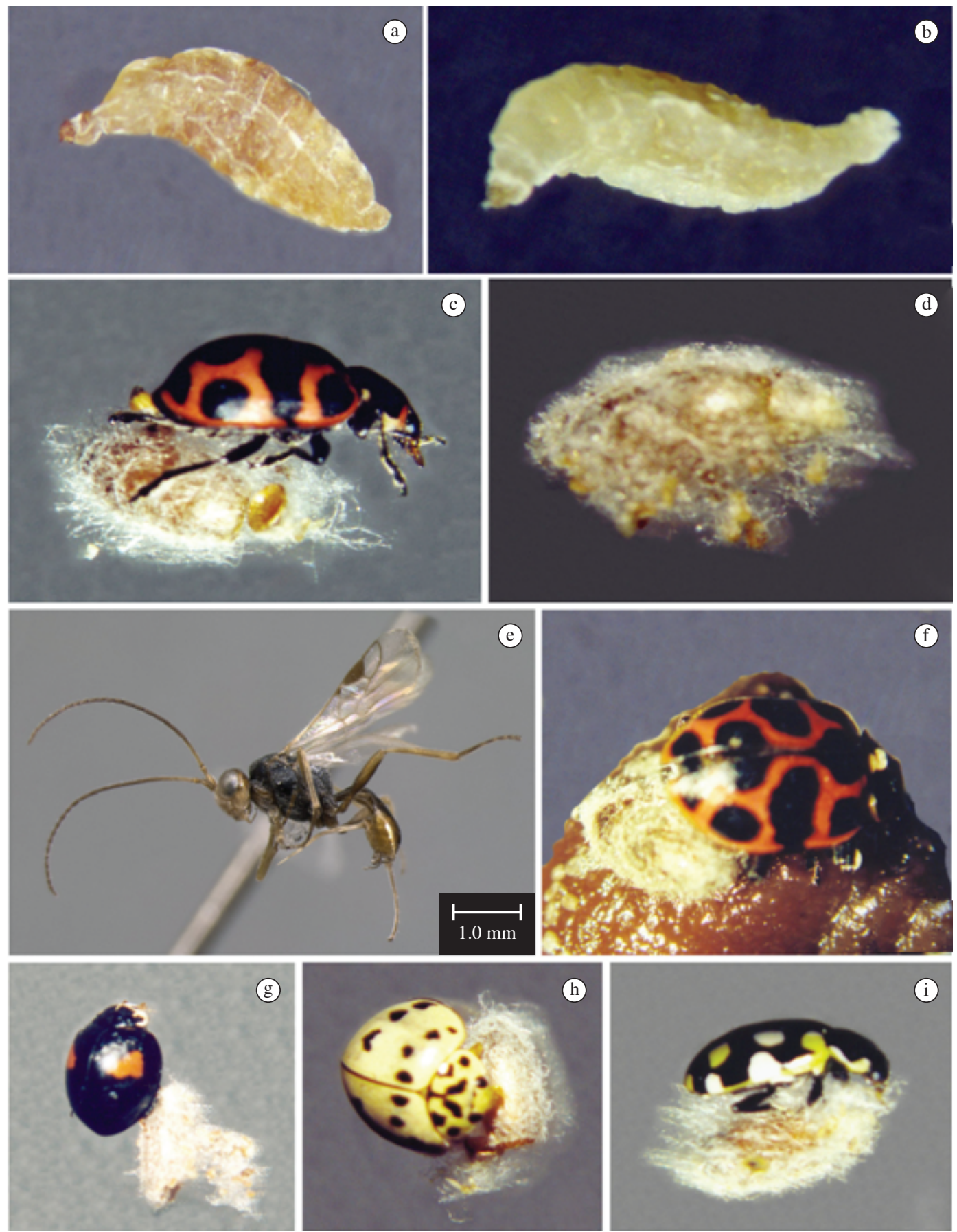

Figures 1. a) and b) Larvae of D. coccinellae; c) Adult of $C$. maculata trapped by the pupa of D. coccinellae; d) Pupa of $D$. coccinellae; e) Adult of $D$. coccinellae; f) Adult of $C$. maculata trapped by the pupa of $D$. coccinellae; g-h) Adults of $O$. v-nigrum trapped by the pupa of $D$. coccinellae; i) Adult of $E$. connexa trapped by the pupa of $D$. coccinellae.

Adults of D. coccinellae (Figure 1e) have transparent membranous wings, the anterior longer than posterior. Ovipositor stylize-form recorded from the ventral side of the abdomen.

Coleomegilla maculata (Figure 1f) presented high mortality index, probably due to adult imprisonment by the pupa of the parasitoid, unlike the other hosts, where the percentage of adults imprisoned E. connexa (Figure 1g) and $O$. v-nigrum (Figures $1 \mathrm{~h}$ and $1 \mathrm{i}$ ) was low.

The period of time between exiting from host and pupation was approximately five hours. Pupa stage period of $D$. coccinellae (Table 1) was similar when the predator 
Table 1. Biological cycle (Mean \pm Standard Error, SE) of D. coccinellae on different species of Coccinellidae, under acclimatised room (temperature of $25 \pm 1{ }^{\circ} \mathrm{C}$, Photoperiod of 12 hours and Relative Humidity of $70 \pm 10 \%$ ) in Sete Lagoas, Minas Gerais state, Brazil.

\begin{tabular}{lccccc}
\hline \multirow{2}{*}{ Hosts } & \multicolumn{5}{c}{ Period of time (days) } \\
\cline { 2 - 6 } & Egg to pupa & Pupa & Egg to adult & Longevity & Total life cycle \\
\hline C. maculata & $18.1 \pm 0.42^{\mathrm{b}}$ & $7.4 \pm 0.14^{\mathrm{b}}$ & $25.5 \pm 0.44^{\mathrm{b}}$ & $6.9 \pm 0.19^{\mathrm{a}}$ & $32.4 \pm 0.48^{\mathrm{b}}$ \\
E. connexa & $13.6 \pm 0.41^{\mathrm{a}}$ & $7.1 \pm 0.34^{\mathrm{b}}$ & $20.7 \pm 0.54^{\mathrm{a}}$ & $7.1 \pm 0.28^{\mathrm{a}}$ & $27.8 \pm 0.40^{\mathrm{a}}$ \\
O. v-nigrum & $16.6 \pm 0.33^{\mathrm{a}}$ & $6.1 \pm 0.24^{\mathrm{a}}$ & $22.7 \pm 0.51^{\mathrm{a}}$ & $6.8 \pm 0.19^{\mathrm{a}}$ & $29.5 \pm 0.49^{\mathrm{a}}$ \\
\hline
\end{tabular}

Means followed by the same letter, per column, do not differ $(\mathrm{p}<0.05)$, by Kruskal-Wallis test.

was associated to C. maculata or E. connexa hosts. After the emergence, the adult parasitoids remained at rest for approximately one hour. If disturbed, they simulate a death condition, at the bottom of the plastic cup with the antennae and wings not expanded.

Egg-adult period of $D$. coccinellae (Table 1) varied according to hosts being shorter when associated to E. connexa or O. v-nigrum. However, adult longevity of D. coccinellae (Table 1) was similar between hosts.

The total life cycle of $D$. coccinellae (Table 1) was shorter when the insect was associated to E. connexa or $O$. v-nigrum than when in association to $C$. maculata.

Seventy percent of $C$. maculata adults were parasitised by $D$. coccinellae; parasitism was 43.3 and $36.7 \%$, when the hosts were $O$. v-nigrum or E. connexa, respectively. Mortality over $94 \%$ was observed in Coleomegilla maculata compared to 60 and $22 \%$ in the case of, E. connexa and O. v-nigrum hosts, respectively.

\section{Discussion}

Male specimens were not obtained, which confirms literature information about telitokous parthenogenesis reproduction mode in D. coccinellae (Balduf, 1926; Phillips and Emberson, 1999; Okuda and Ceryngier, 2000).

Results confirmed that $C$. maculata is an important host to D. coccinellae (Hudon, 1959; Obrycki and Tauber, 1979; Obrycki et al., 1985; Firlej et al., 2005), since the percentage of parasitism was superior to the parasitism obtained when the parasitoid was associated to the other hosts. Coccinellids vary in their suitability as hosts for D. coccinellae (Orr et al., 1992; Firlej et al., 2006; Koyama and Majerus, 2008), but the mechanisms that influence realised rates of parasitism of various coccinellid species are unknown for many species (Riddick et al., 2009).

The results obtained in the laboratory suggest that field efficiency of biological control programme using the Coccinellidae species, C. maculata, E. connexa and $O$. v-nigrum can fail due to parasitism by $D$. coccinellae. On the other hand, the action of multiple natural enemies on this Coccinellidae can provide a greater impact on population dynamic than any one species acting alone.

Acknowledgements - To the Instituto Nacional de Ciência e Tecnologia dos Hymenoptera Parasitoides da Região Sudeste Brasileira - HYMPAR/Sudeste-CNPq/FAPESP/CAPES), for financial support for this research and to Dra. Luciana Bueno dos Reis Fernandes for the assistance in the formatting of photos.

\section{References}

BALDUF, WV., 1926. The bionomics of Dinocampus coccinellae Schrank. Annals of the Entomological Society of America, vol. 19, p. 465-498.

FIRLEJ, A., BOIVIN, G., LUCAS, E. and CODERRE, D., 2005. First report of Harmonia axyridis Pallas being attacked by Dinocampus coccinellae Schrank in Canada. Biological Invasions, vol. 7, p. 553-556. http://dx.doi.org/10.1007/s10530-004-5848-0

FIRLEJ, A., LUCAS, E., CODERRE, D. and BOIVIN, G., 2006. Teratocytes growth pattern reflects host suitability in a hostparasitoid assemblage. Physiological Entomology, vol. 32, p. 181-187. http://dx.doi.org/10.1111/j.1365-3032.2006.00548.x

GEOGHEGAN, IE., MAJERUS, TMO. and MAJERUS, MEN., 1998. Differential parasitisation of adult and pre-imaginal Coccinella septempunctata (Coleoptera: Coccinellidae) by Dinocampus coccinellae (Hymenoptera: Braconidae). European Journal of Entomology, vol. 95, p. 571-579.

GRAVENA, S., 1978. Occurrence of parasitism in Cycloneda sanguinea (Linnaeus, 1763) in Jaboticabal, SP, Brazil. Anais da Sociedade Entomológica do Brasil, vol. 20, p. 69-70.

HODEK, I., 1973. Biology of Coccinellidae. Prague: Czechoslovak Academic of Sciences. $260 \mathrm{p}$

HOOGENDOORN, M. and HEIMPEL GE., 2002. Indirect interactions between an introduced and a native ladybird beetle species mediated by a shared parasitoid. Biological Control, vol. 25, p. 224-230. http://dx.doi.org/10.1016/S1049-9644(02)00101-9

HUDON, M., 1959. First record of Perilitus coccinellae (Schrank) (Hymenoptera: Braconidae) as a parasite of Coccinella novemnotata Hbst. and Coleomegilla maculata lengi Timb. (Coleoptera: Coccinellidae) in Canada. Canadian Entomologist, vol. 91, p. 63-64. http://dx.doi.org/10.4039/Ent9163-1

ISIKBER, AA. and COPLAND, MJW., 2002. Effects of various aphid foods on Cycloneda sanguinea. Entomologia Experimentalis et Applicata, vol. 102, p. 93-97. http://dx.doi.org/10.1046/j.15707458.2002.00928.x

KATSAROU, I., MARGARITOPOULOS, JT., TSITSIPIS, JA., PERDIKIS, DC. and ZARPAS, KD., 2005. Effect of temperature on development, growth and feeding of Coccinella septempunctata and Hippodamia convergens reared on the tobacco aphid, Myzus persicae nicotianae. BioControl, vol. 50, p. 565-588. http://dx.doi. org/10.1007/s10526-004-2838-1

KOYAMA, S. and MAJERUS, MEN., 2008. Interactions between the parasitoid wasp Dinocampus coccinellae and two species of coccinellid from Japan and Britain. BioControl, vol. 53, p. 253264. http://dx.doi.org/10.1007/s10526-007-9138-5 
KRUSKAL, W. and WALLIS, WA., 1952. Use of ranks in onecriterion variance analysis. Journal of the American Statistical Association, vol. 47, p. 583-621. http://dx.doi.org/10.2307/2280779

LU, W., SOUPHANY, P. and MONTGOMERY, ME., 2002. Descriptions of immature stages of Scymnus (Neopullus) sinuanodulus $\mathrm{Yu}$ and Yao (Coleoptera: Coccinellidae) with notes on life history. The Coleopterists Bulletin, vol. 56, p. 127-141. http://dx.doi. org/10.1649/0010-065X(2002)056[0127:DOISOS]2.0.CO;2

LUNDGREN, JG., 2009. Nutritional aspects of non-prey foods in the life histories of predaceous Coccinellidae. Biological Control, vol. 51, p. 294-305.

MAJERUS, MEN., GEOGHEGAN, IE. and MAJERUS, TMO., 2000. Adaptive preferential selection of young coccinelid hosts by the parasitoid wasp Dinocampus coccinellae (Hymenoptera: Braconidae). European Journal of Entomology, vol. 97, p. 161-164.

OBRYCKI, JJ., 1989. Parasitization of native and exotic coccinellids by Dinocampus coccinellae (Schrank) (Hymenoptera: Braconidae). Journal of the Kansas Entomological Society, vol. 62, p. 211-218.

OBRYCKI, JJ. and TAUBER, MJ., 1979. Seasonal synchrony of the parasite Perilitus coccinellae and its host Coleomegilla maculata. Environmental Entomolology, vol. 8, p. 400-405.

OBRYCKI, JJ., TAUBER, MJ. and TAUBER, CA., 1985. Perilitus coccinellae (Hymenoptera: Braconidae): parasitization and development in relation to host-stage attacked. Annals of the Entomological Society of America, vol. 78, p. 852-854.

OBRYCKI, JJ., HARWOOD, JD., KRING, TJ. and O'NEIL, RJ., 2009. Aphidophagy by Coccinellidae: application of biological control in agroecosystems. Biological Control, vol. 51, p. 244-254. http://dx.doi.org/10.1016/j.biocontrol.2009.05.009

OKUDA, T. and CERYNGIER, P., 2000. Host discrimination in Dinocampus coccinellae (Hymenoptera: Braconidae), a solitary parasitoid of coccinellid beetles. Applied Entomology and Zoology, vol. 35, p. 535-539. http://dx.doi.org/10.1303/aez.2000.535

OMKAR, MISHRA, G. and SINGH, SK., 2006. Optimal number of matings in two aphidophagous ladybirds. Ecological Entomology, vol. 31, p. 1-4. http://dx.doi.org/10.1111/j.0307-6946.2006.00751.x
ORR, CJ., OBRYCKI JJ. and FLANDERS RV., 1992. Hostacceptance behavior of Dinocampus coccinellae (Hymenoptera: Braconidae). Annals of the Entomological Society of America, vol. 85 , p. 722-730.

PHILLIPS, CB. and EMBERSON, RM., 1999. Morphological discriminations between first instar larvae of four euphorine parasitoids. BioControl, vol. 44, p. 159-169. http://dx.doi. org/10.1023/A:1009929427588

RIDDICK, EW., COTTRELAND, TE. and KIDD, KA., 2009. Natural enemies of the Coccinellidae: parasites, pathogens, and parasitoids. Biological Control, vol. 51, p. 306-312. http://dx.doi. org/10.1016/j.biocontrol.2009.05.008

SANTOS, GP. and PINTO, ACQ., 1981. Biology Cycloneda sanguinea and its association with aphids on leaves of mango. Pesquisa Agropecuária Brasileira, vol. 16, p. 473-476.

SEGONÇA, C., AL-ZYOUD, F. and BLAESER, P., 2005. Prey consumption by larval and adult stages of the entomophagous ladybird Serangium parcetosum Sicard (Col., Coccinellidae) of the cotton whitefly, Bemisia tabaci (Genn.) (Hom., Aleyrodidae), at two different temperatures. Journal of Pest Science, vol. 78, p. $179-186$.

SILVA, RB., CRUZ, I., FIGUEIREDO, MLC. and TAVARES, WS., 2010. Development of Coleomegilla maculata De Geer (Coleoptera: Coccinellidae) with prey and artificial diet. Revista Brasileira de Milho e Sorgo, vol. 9, p. 13-26.

SILVA, RB., ZANUNCIO, JC., SERRÃO, JE., LIMA, ER., FIGUEIREDO, MLC. and CRUZ, I., 2009. Suitability of different artificial diets for development and survival of stages of predaceous ladybird beetle Eriopis connexa (Coleoptera: Coccinellidae). Phytoparasitica, vol. 37, p. 115-123. http://dx.doi.org/10.1007/ s12600-008-0015-2

WEBER, DC. and LUNDGREN, JG., 2009. Assessing the trophic ecology of the Coccinellidae: their roles as predators and as prey. Biological Control, vol. 51, p. 199-214. http://dx.doi.org/10.1016/j. biocontrol.2009.05.013

STATHAS, GJ., 2000. Rhyzobius lophanthae prey consumption and fecundity. Phytoparasitica, vol. 28, p. 203-211. http://dx.doi. org/10.1007/BF02981798 
